\title{
Pengaruh Papain Getah Pepaya Terhadap Pembentukan Jaringan Granulasi pada Penyembuhan Luka Bakar Tikus Percobaan
}

\author{
Meishinta Fitria ${ }^{1}$, Deddy Saputra ${ }^{2}$, Gusti Revilla ${ }^{3}$
}

\begin{abstract}
Abstrak
Luka bakar merupakan masalah yang serius dalam kesehatan dunia, khususnya di negara berkembang. Di Indonesia belum ada laporan tertulis mengenai jumlah penderita luka bakar dan jumlah angka kematian yang diakibatkannya. Di RSUP Dr. M. Djamil Padang pada tahun 2010 ditemukan 84 kasus luka bakar dengan penyebab sengatan listrik, siraman air panas, kompor, dan minyak panas. Sejumlah studi menunjukkan bahwa tanaman tradisional potensial sebagai agen penyembuhan luka, salah satunya papain getah pepaya (Carica papaya). Penelitian ini bertujuan untuk mengetahui pembentukan jaringan granulasi pada penyembuhan luka bakar tikus percobaan. Jenis penelitian ini adalah penelitian eksperimental dengan rancangan posttest only control group design. Subjek penelitian adalah 10 ekor tikus Wistar jantan yang dibagi menjadi dua kelompok, yaitu kelompok kontrol (K) dan kelompok perlakuan $(P)$. Masing-masing kelompok terdiri dari lima (5) ekor tikus. Plat logam $(1,5 \mathrm{~cm} \times 1,5 \mathrm{~cm})$ yang dipanaskan digunakan untuk menghasilkan luka bakar full thickness pada bagian dorsal tikus. Papain getah pepaya diberikan pada kelompok $\mathrm{P}$ selama 7 hari. Hasil penelitian ini menunjukkan bahwa pemberian papain getah pepaya tidak memberikan pengaruh yang signifikan $(p>0,05)$ terhadap pembentukan jaringan granulasi pada penyembuhan luka bakar tikus percobaan. Pada kelompok $P$ didapatkan hasil pembuluh darah 29,26 $\pm 12,34$, fibroblas $26,40 \pm 21,94$, neutrofil $1,4 \pm 0,44$, limfosit $1,06 \pm 0,13$, dan makrofag $1,00 \pm 0,00$. Kesimpulan penelitian ini adalah papain getah pepaya tidak memberikan pengaruh yang signifikan terhadap pembentukan jaringan granulasi pada penyembuhan luka bakar tikus percobaan
\end{abstract}

Kata kunci: papain, jaringan granulasi, luka bakar, penyembuhan luka

\begin{abstract}
Burn wounds is the serious problem in world health specifically for developing contries. In Indonesia, there is no written report about burn wounds patient and mortality account yet. In 2010, M. Djamil Padang Government Public Hospital found 84 cases of burn wounds with some causes as burn effect from sting of electric, hot water, stove flame and hot oil. Some researches indicate that traditional plant able to be wound healing agent as papaya sap. The purposed of this studi was to find out the effect of papain from papaya sap to granulation tissue formation on burn wounds healing in rat models. This was experimental research with posttest only control group design. The subjects were ten male Wistar rats divided in to two group (control group $K$ and experimental group $P$ ). Every group consist of five rats. Heated metal plat $(1,5 \mathrm{~cm} \times 1,5 \mathrm{~cm})$ used to get full thickness burn wound on dorsal rat part. Then, papain of papaya sap was given to group $P$ for seven days. The results showed that papain of papaya sap didn't have significant effect $(p>0,05)$ to granulation tissue formation in burn wound healing of rat models. In group $P$, the research found the vascular 29,26 $\pm 12,24$, fibroblast $26,40 \pm 21,94$, neutrophil 1,4 $\pm 0,44$, lymphocyte 1,06 $\pm 0,13$, and macrophag 1,00 \pm 0,00 . The conclusion of this research is that papain of papaya sap didn't have the significant effect to granulation tissue formation in burn wound healing of rat models.
\end{abstract}

Keywords:papain, granulation tissue, burn, wound healing

Affiliasi penulis: ${ }^{1}$ Fakultas Kedokteran Unand, ${ }^{2}$ Bagian IImu Bedah FK Unand, ${ }^{3}$ Bagian Anatomi FK Unand

Korespondensi ; Maishinta Fitria, Padang. Email: meishinta_fitria@ymail.com, Telp: 081977591007

\section{PENDAHULUAN}

Luka bakar merupakan masalah yang serius dalam kesehatan dunia, khususnya di negara berkembang. ${ }^{1}$ Pada tahun 2008, lebih dari 410000 luka bakar terjadi di Amerika Serikat, dengan sekitar 40000 membutuhkan perawatan rumah sakit. Di India, lebih dari 1 juta orang mengalami luka bakar setiap tahun. ${ }^{2} \mathrm{Di}$ Indonesia, belum ada laporan tertulis mengenai jumlah penderita luka bakar dan jumlah angka kematian yang diakibatkannya. Di RSUP M.Jamil Padang pada tahun 2009 dilaporkan bahwa kasus luka bakar mencapai 91 orang dengan penyebab berasal dari kompor dan alat elektronik. Pada tahun 2010 ditemukan 84 kasus luka bakar dengan penyebab sengatan listrik 22 kasus (26\%), siraman air panas 15 kasus, dan sisanya dengan penyebab api, kompor gas dan minyak panas. ${ }^{3}$

Luka bakar akan menimbulkan kerusakan berbagai organ, diantaranya kulit. Sebagai respon terhadap jaringan yang rusak, tubuh memiliki kemampuan untuk mengganti jaringan yang rusak, memperbaiki struktur, kekuatan, dan fungsinya melalui proses penyembuhan luka. ${ }^{4}$ Proses penyembuhan luka merupakan proses yang kompleks dan dinamis yang melibatkan interaksi antara sel dan mediator yang berbeda. ${ }^{5}$

Proses penyembuhan luka bakar dibagi menjadi tiga fase, yaitu fase inflamasi, proliferasi, dan 
maturasi yang terjadi pada luka bakar derajat II dan III. Pada fase proliferasi terjadi pembentukan jaringan granulasi yang merupakan pusat dari fase proliferasi.Pembentukan jaringan granulasi ini dimulai empat hari setelah luka.Jaringan granulasi ini terdiri dari makrofag, fibroblas, dan pembuluh darah. Makrofag menghasilkan faktor pertumbuhan yang diperlukan untuk merangsang pembentukan fibroblas dan pembuluh darah. Fibroblas menghasilkan matriks ekstraseluler baru dan pembuluh darah membawa oksigen dan nutrisi yang diperlukan untuk mempertahankan metabolisme sel. ${ }^{6}$

Sejumlah studi menunjukkan bahwa tanaman tradisional potensial sebagai agen penyembuhan luka disamping pengobatan medis untuk luka bakar ringansedang. Sebagian besar disukai masyarakat karena ketersediaan yang luas dan tidak ada efek samping, seperti madu lebah, lidah buaya, dan getah pepaya (Carica papaya). Batang, daun, dan buah Carica papaya menghasilkan getah. Getah tanaman Carica papaya ini mengandung enzim (papain) dan substansi antibakterial (carpain) yang mempunyai efek positif dalam penyembuhan luka bakar. ${ }^{1}$

Berdasarkan klasifikasi The International Union of Biochemistry, papain termasuk enzim hidrolase yang mengkatalisis reaksi hidrolisis suatu substrat dengan pertolongan molekul air. Aktivitas katalisis papain dilakukan melalui hidrolisis yang berlangsung pada sisi-sisi aktif papain. Pemisahan gugus amida yang terdapat di dalam protein tersebut berlangsung melalui pemutusan ikatan peptida. Enzim ini mempunyai aktivitas katalitik sebagai proteinase dan sanggup menghidrolisis peptide. ${ }^{7}$

Papain yang merupakan salah satu agen enzymatic debridement dapat mencerna jaringan nekrotik karena mempunyai aktivitas katalitik dengan mencairkan eschar (keropeng yang dihasilkan luka bakar) sehingga memudahkan migrasi sel dari tepi luka ke daerah luka.Papain juga berguna dalam mengurangi infeksi bakteri, mengurangi eksudat dan meningkatkan pembentukan jaringan granulasi. Dalam penelitiannya ini, Telgenhoff dkk / 2007) menggunakan Papain-urea copper chlorophyllin (PUC) dengan komposisi papain $8 \%$, urea $10 \%$, dan chlorophyllin $0,5 \%{ }^{8} \quad$ Selain itu, papain juga dapat meningkatkan angiogenesis. $^{9} \quad$ Tujuan penelitian ini adalah mengetahui pengaruh papain getah pepaya terhadap pembentukan jaringan granulasi pada penyembuhan luka bakar tikus percobaan.

\section{METODE}

Jenis penelitian ini adalah eksperimental dengan rancangan posttest only control group design . Penelitian dilaksanakan di laboratorium Anatomi dan laboratorium Patologi Anatomi Fakultas Kedokteran Universitas Andalas mulai Maret 2013 sampai Oktober 2013. Populasi adalah tikus jantan yang ada di Laboratorium Farmakologi Fakultas Farmasi Universitas Andalas. Sampel adalah bagian dari populasi yang memenuhi kriteria inklusi dan eksklusi.Kriteria inklusi meliputi tikus jantan, berat 180 gram - 200 gram, dan umur 2 bulan.Kriteria Eksklusi adalah tikus sakit dan tikus mati. Besar sampel ditentukan dengan rumus Fraenkle dan Walles : (np 1) $-(p-1) \geq p^{2}$ dengan $p=$ jumlah kelompok hewan percobaan dan $n=$ jumlah hewan coba tiap kelompok. Berdasarkan rumus tersebut, maka besar sampel yang digunakan dalam penelitian ini adalah 5 sampel untuk tiap kelompok. Variabel independen yaitu pemberian papain getah papaya dan variabel dependen yaitu pembentukan jaringan granulasi. Data didapatkan melalui penilaian jaringan granulasi dengan menghitung jumlah pembuluh darah baru, fibroblas serta kepadatan sel radang. Penghitungan jumlah pembuluh darah baru dan fibroblas pada sediaan hispatologi menggunakan mikroskop cahaya pada perbesaran $40 \times 10$. Pengamatan sel radang dilakukan dengan mengamati kepadatan sel neutrofil, limfosit, dan makrofag pada sediaan histopatologi menggunakan mikroskop cahaya dengan perbesaran $40 \times 10{ }^{10}$ Pengamatan dilakukan pada 3 lapang pandang kemudian dirata-ratakan.Penilaian pembuluh darah dan fibroblas menggunakan skala numerik sedangkan penilaian sel radang menggunakan skala ordinal.

Prosedur pengambilan dan pengumpulan data dilakukan dengan mempersiapkan tikus percobaan dan papain. Tikus diberi makan dan minum, dipelihara pada kandang yang telah diberi sekat pemisah untuk tiap-tiap tikus. Enzim papain dalam bentuk liquid dengan kandungan $25 \mathrm{mg}$ dalam $1,2 \mathrm{ml}$ yang diperoleh dari pabrik Nacalai Tesque Kyoto Jepang dicampur dengan vaselin dan disimpan di dalam freezer. Setiap tikus diberi injeksi Lidokain i.m. sebanyak $1 \mathrm{cc}$. Tikus diberi anestesi eter kemudian rambut tikus bagian punggung dibersihkan menggunakan pisau sampai permukaan kulitnya terlihat seluas $2,5 \mathrm{~cm} \times 2,5 \mathrm{~cm}$. Plat yang sudah dipanaskan di dalam air mendidih (suhu $100^{\circ} \mathrm{C}$ ) selama setengah jam ditempelkan pada permukaan kulit tikus selama 20 detik untuk membuat luka bakar full thicknes. ${ }^{9}$ Kemudian tikus diberikan injeksi Decamidon sebagai analgetik. Kelompok tikus kontrol dimasukkan ke dalam 1 kandang yang telah diberi sekat pemisah.Kelompok tikus perlakuan diberikan papain yang telah dicampur dengan vaselin yang dioleskan pada daerah luka bakar dan dimasukkan ke dalam 1 kandang yang telah diberi sekat pemisah. Masing-masing tikus diberi makan dan minum dengan tempat yang berbeda untuk setiap tikus. Pada hari ke7 tikus diberi anestesi eter kemudian dikorbankan dengan cara dislokasi servikal dan dilakukan penyayatan pada kulitnya. Kulit yang telah disayat kemudian disimpan dalam botol yang telah diisi dengan formalin dan diberi kode untuk tiap-tiap botol. Kulit tersebut dibuat preparat histologis dengan pewarnaan HE dan kemudian dinilai pembentukan jaringan granulasinya di bawah mikroskop oleh dokter ahli patologi anatomi dan peneliti di laboratorium Patologi Anatomi Fakultas Kedokteran Universitas Andalas. Semua data ditabulasikan menurut kelompoknya, kemudian dihitung rata-rata (mean) dan standard deviasi untuk setiap kelompok. Perbedaannya dianalisis dengan SPSS 17.0 menggunakan $t$-test untuk data pembuluh darah dan fibroblas serta Mann Whitney test untuk datasel radang. Perbedaan dinyatakan bermakna apabila $p \leq$ 0,05 .

HASIL

Pembentukan jaringan granulasi dinilai dengan mengamati pembentukan pembuluh darah, fibroblas, dan sel radang (neutrofil, limfosit, makrofag).Hasil pengamatan pembuluh darah, 
fibroblast, dan sel radang dapat dilihat pada tabel 1.

Tabel 1. Hasil analisis data jaringan granulasi

\begin{tabular}{cccc}
\hline Variabel & $\begin{array}{c}\mathbf{K} \\
(\mathbf{n}=5)\end{array}$ & $\begin{array}{c}\mathbf{P} \\
(\mathbf{n}=5)\end{array}$ & $\mathbf{p}$ \\
\hline Pembuluh Darah & $18,06 \pm 8,29$ & $29,26 \pm 12,34$ & $\mathbf{0 , 1 3 1}$ \\
& & & \\
Fibroblas & 21,20 & $26,40 \pm 21,94$ & $\mathbf{0 , 7 0 4}$ \\
& $\pm 19,70$ & & \\
Neutrofil & $1,78 \pm 0,45$ & $1,4 \pm 0,44$ & $\mathbf{0 , 1 6 3}$ \\
Limfosit & $1,00 \pm 0,00$ & $1,06 \pm 0,13$ & $\mathbf{0 , 3 1 7}$ \\
Makrofag & $1,54 \pm 0,50$ & $1,00 \pm 0,00$ & $\mathbf{0 , 0 5 3}$ \\
\hline
\end{tabular}

Keterangan:

$\mathrm{n} \quad$ : Jumlah hewan percobaan

K : Kelompok kontrol

$\mathrm{P} \quad$ : Kelompok perlakuan

Data disajikan dalam bentuk Mean \pm SD

Data perbedaan $(p)$ dinyatakan bermakna jika $p \leq 0,05$

Hasil pengamatan pembentukan jaringan granulasi pada kelompok kontol $(\mathrm{K})$ yaitu, pembuluh darah adalah 18,06 $\pm 8,29$, fibroblas adalah 21,20 $\pm 19,70$, neutrofil adalah $1,78 \pm 0,45$, limfosit adalah $1,00 \pm 0,00$, makrofag 1,54 $\pm 0,50$. Sedangkan pada kelompok perlakuan (P) didapatkan hasil pembuluh darah $29,26 \pm 12,34$, fibroblas $26,40 \pm 21,94$, neutrofil $1,4 \pm 0,44$, limfosit $1,06 \pm 0,13$, dan makrofag $1,00 \pm$ 0,00 .

Pada analisis data hasil pengamatan pembentukan jaringan granulasi tersebut ditemukan bahwa tidak terdapat pengaruh signifikan $(p>0,05)$ pada pembentukan jaringan granulasi (pembuluh darah, fibroblas, neutrofil, limfosit, dan makrofag.
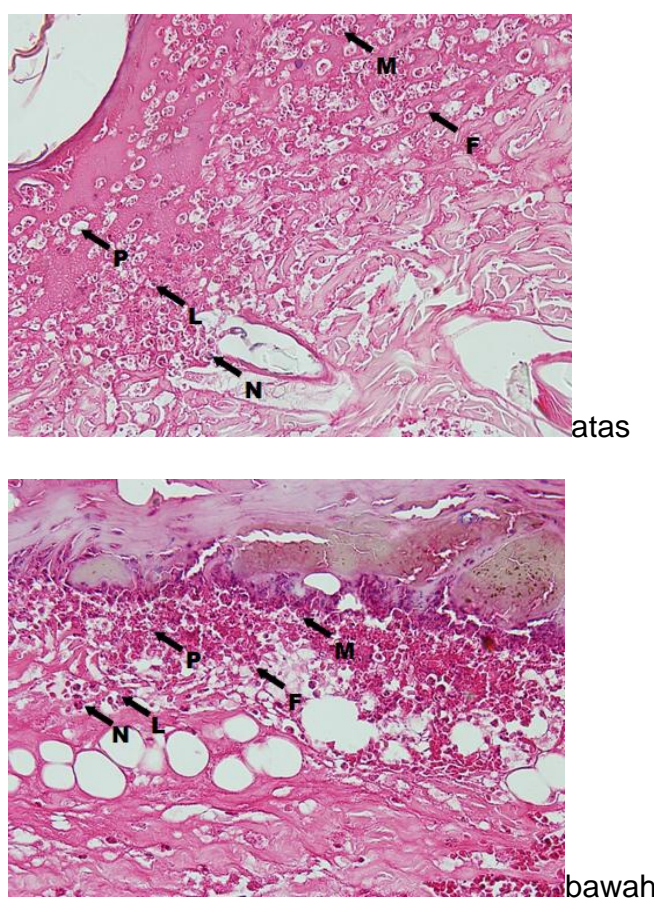

Gambar 1. Jaringan granulasi pada kelompok kontrol (atas) dan kelompok perlakuan (bawah) pada pembesaran $40 \times 10$. Terlihat pembuluh darah $(P)$ sel limfosit (L) makrofag (M), neutrofil (N) dan penyebaran sel-sel fibroblas $(F)$.

\section{PEMBAHASAN}

Pengamatan pada preparat histopatologi dilakukan dengan menghitung jumlah pembuluh darah, fibroblas, dan sel radang (neutrofil, limfosit, makrofag). Hasil pengolahan analisis data penelitian menunjukkan bahwa pemberian papain getah pepaya tidak memberikan pengaruh yang signifikan secara statistik terhadap pembentukan jaringan granulasi pada penyembuhan luka bakar tikus percobaan.

Dalam proses penyembuhan luka, fase inflamasi berlangsung pada hari sejak terjadinya luka sampai kira-kira hari keempat. Pada pengamatan histopatologi, dapat dilihat adanya sel radang yang menunjukkan masih berlangsungnya fase inflamasi pada beberapa sampel (Gambar 1). Hal ini dapat menyebabkan tidak maksimalnya hasil pengamatan pembentukan jaringan granulasi. Namun, dari pengamatan rata-rata skor sel radang lebih kecil pada kelompok papain dibanding kelompok kontrol, kecuali limfosit.

Pembentukan jaringan granulasi merupakan pusat fase proliferasi dari penyembuhan luka. Pembentukan jaringan granulasi ini dimulai empat hari setelah luka. Jaringan granulasi ini terdiri dari makrofag, fibroblast, dan pembuluh darah. Makrofag menghasilkan faktor pertumbuhan yang diperlukan untuk merangsang pembentukan fibroblast dan pembuluh darah diantaranya transforming growth factor- $\beta$ (TGF- $\beta$ ) dan vascular endothelial growth factor (VEGF). ${ }^{11} \quad$ Menurunnya kadarTGF- $\beta$ menunjukkan bahwa papain dapat mengurangi terjadinya fase inflamasi yang memanjang, mengurangi infiltrasi monosit dan mempercepat fase lain dari penyembuhan luka. ${ }^{12}$ Fibroblast menghasilkan matriks ekstraseluler baru. Pada penelitian ini rata-rata pembentukan fibroblas pada kelompok papain $(26,40 \pm 21,94)$ lebih banyak dibandingkan kelompok kontrol $(21,20 \pm 19,70)$ tetapi tidak berbeda secara signifikan. Fibroblas ini lebih aktif mensintesis komponen matriks sebagai respon terhadap luka. Migrasi dan proliferasi fibroblas terutama dipacu oleh transforming growth factor- $\beta$ (TGF- $\beta$ ). Migrasi dan peningkatan proliferasi fibroblas di daerah luka akan meningkatkan sintesis kolagen. Kolagen akan memberikan kekuatan dan integritas pada luka yang menyembuh dengan baik. Pembuluh darah membawa oksigen dan nutrisi yang diperlukan untuk mempertahankan metabolisme sel. Pada penelitian ini terlihat bahwa rata-rata pembentukan pembuluh darah pada kelompok papain $(29,26 \pm$ $12,34)$ lebih banyak dibandingkan kelompok kontrol $(18,06 \pm 8,29)$ tetapi tidak berbeda secara signifikan ( $p>0,05)$. Pembentukan pembuluh darah baru dirangsang oleh faktor pertumbuhan angiogenik seperti transforming growth factor- $\beta$ (TGF- $\beta$ ) dan vascular endothelial growth factor (VEGF). Faktor pertumbuhan ini berikatan dengan reseptor pada permukaan endotel. Sel endotel teraktivasi kemudian berproliferasi dan tumbuh keluar melalui membran basalis sehingga terbentuk tunas kapiler yang akan menjadi pembuluh darah baru. Pembentukan pembuluh darah baru akan mempengaruhi lamanya proses penyembuhan luka. ${ }^{13}$

Hasil penelitian ini berbeda dengan penelitian Telgenhoff dkk yang pada tahun 2007 juga melakukan penelitian mengenai penyembuhan luka. Penelitian ini menggunakan papain urea copper chlorophyillin (PUC) yang dibandingkan dengan pengobatan lainnya seperti papain urea, copper chlorophyllin, urea,dankontrol. Pada penelitian yang dilakukan pada babi ini ditemukan bahwa vaskularisasi meningkat pada kelompok yang diberi PUC, papain urea, copper chlorophyllin; reepitelisasi meningkat pada kelompok 
PUC dan papain; kolagen meningkat pada kelompok PUC. ${ }^{8}$

Dari penelitian pengaruh papain getah pepaya terhadap pembentukan jaringan granulasi pada penyembuhan luka bakar, didapatkan kesimpulan bahwa pembentukan pembuluh darah dan fibroblas lebih banyak pada kelompok yang diberi papain dibanding kelompok tanpa papain, sedangkan rata-rata skor kepadatan sel radang (neutrofil, limfosit, makrofag) lebih kecil pada kelompok yang diberi papain dibanding kelompok tanpa papain, kecuali limfosit (lebih sedikit pada kelompok tanpa papain). Namun, pemberian papain getah pepaya tidak memiliki perbedaan yang signifikan secara statistik terhadap pembentukan jaringan granulasi pada penyembuhan luka bakar baik pembuluh darah, fibroblas maupun sel radang (limfosit, neutrofil, makrofag).

\section{DAFTAR PUSTAKA}

1. Lin TS, Azian AL, Srijit D. Use of traditional herbal extracts in treatment of burn wound. Journal of Clinical Dermatology 2010: 1-5.

2. World Health Organization Burn (diunduh 10 Maret 2013) 2012. Tersedia dari: URL: HYPERLINK http://www.who.int/mediacentre/ factsheets/fs365/en/

3. RSUP Dr. M. Djamil Padang. Data kasus luka bakar 2009-2010. 2011

4. Georgiade SG, Christopher WP. Luka bakar. Dalam: Buku Ajar Bedah Jilid 1. Edisi ke-17. Jakarta: Penerbit Buku Kedokteran EGC; 2011. hlm. 151-63

5. Pan SC, Li WW, Chung LC, Shyh JS, Haw YC. Deep partial thickness burn blister fluid promotes neovascularization in the early stage of burn wound healing. Wound Repair and Regeneration. 2009
6. Grace PA, Neil RB. Luka bakar. Dalam: At a Glance IImu Bedah. Jakarta: Erlangga; 2006. hlm. 86-9.

7. Wibisono E. Imobilisasi crude enzim papain yang diisolasi dari getah buah pepaya (carica papaya) dengan menggunakan kappa karagenan dan kitosan serta pengujian aktivitas dan stabilitasnya (skripsi). Medan: Universitas Sumatera Utara; 2010.

8. Telgenhoff D, Kan L, Sarah R, Valerie V, Kristine $\mathrm{V}$, Paul S, et al. Influence of papain urea copper chlorophyllin on wound matrix remodeling. Wound Repair and Regeneration. 2007; 15: 727-35.

9. Shud AN, Mohd SA, Ahmad AY. The effects of carica papaya linn. latex on the healing of burn wounds in rats. Jurnal Sains Kesihatan Malaysia. 2005; 3: 39-47.

10. Pratiwi M. Efek ekstrak lerak (Sapindus rarak Dc) $0,01 \%$ terhadap penurunan sel-sel radang pada tikus wistar jantan (penelitian in vivo) (skripsi). Medan: Universitas Sumatera Utara; 2010.

11. Green MM, Melissa P, Lei W. Chemokines and their receptors are key players in the orchestra that regulates wound healing. Wound Care. 2013; 2: 327-47.

12. Revilla G, Yanwirasti. The effectiveness of papain on the level of TGF- $\beta$ in burn in the rat models. Pertemuan IImiah Anatomi di Bali; 12-13 Oktober 2013.

13. Li WW, Dimitris T, Vincent WL. Angiogenesis: A Control Point for Normal and Delayed Wound Healing. Contemporary Surgery. 2003:5-11. 